The figures of 60 per cent bare ground for May 30 in table I should not be understood to mean that the other 40 per cent is fresh growth. Indeed, there is almost nothing green at that time of year. The vegetation cover is made up of the dry grasses, sedges, and flowering herbs of the previous summer. By July $\mathrm{I}$, however, the new growth has reached its maximum. This rapid development is necessitated by the shortness of the growing season. Only such plants as can mature quickly are able to exist under the rigorous climatic conditions.

TABLE II

Percentage of Bare ground in meadow grassland

\begin{tabular}{|c|c|c|c|c|c|c|}
\hline Quadrat & $\underset{\text { IgI } 2}{\text { May } 30}$ & $\begin{array}{l}\text { June I } 2 \text {, } \\
\text { I }_{9} \mathrm{I}_{3}\end{array}$ & $\begin{array}{l}\text { June } 28 \\
\text { I913 }\end{array}$ & $\begin{array}{l}\text { July I } 2 \text {, } \\
\text { I913 }\end{array}$ & $\begin{array}{l}\text { July } 26 \text {, } \\
\text { I91 } 3\end{array}$ & $\begin{array}{l}\text { Sept. I, } \\
\text { I } 9 \text { I 2 }^{2}\end{array}$ \\
\hline $\begin{array}{l}\mathrm{XI}(a) \ldots \ldots \ldots \ldots \\
\text { XIII }(a) \ldots \ldots \ldots \ldots\end{array}$ & $\begin{array}{l}45 \\
25\end{array}$ & $\begin{array}{c}20 \\
\ldots \ldots\end{array}$ & $\begin{array}{r}\circ \\
20\end{array}$ & $\begin{array}{r}0 \\
10\end{array}$ & $\begin{array}{r}\circ \\
10\end{array}$ & $\begin{array}{l}\text { IO } \\
\text { I0 }\end{array}$ \\
\hline Average...... & 35 & 20 & Io & 5 & 5 & I0 \\
\hline
\end{tabular}

In the dry grassland, as will be seen from table I, there is a considerable proportion of bare ground, even at the height of the season in early July. The meadow association, on the other hand, shows little or no vacant space at that time. The differences depend chiefly on the texture of the soil, the finer grained material of the meadow holding more moisture and permitting more luxuriant growth.

It is interesting to note that when introduced weeds get a foothold in the region they do not become established in the open association of dry grassland, but in the already closely grown meadow.-Francis Ramaley, University of Colorado, Boulder, Colo.

\title{
THE OXIDASES OF ACID TISSUES
}

According to recent theories, the oxidases play an essential part in respiration. If these theories are correct, it follows that oxidases must be present in all organisms. But a serious difficulty is encountered in the fact that many plants have been reported to be free from oxidases. If this is really the case, it would seem that these theories must be abandoned, or at least greatly modified.

It appeared to the writer that in view of the importance of the subject a fresh investigation was needed. From the results of the writer's experiments it is evident that in many cases the reported absence of oxidases is to be ascribed to faulty methods of investigation. The 
method which has been almost exclusively used is to express the juice or to make watery extracts of the ground or minced tissue. The ability of these extracts to accelerate the oxidation of such reagents as gum guaiac, a-napthol, hydrochinone, etc., has been taken as an indication of the presence of oxidases in the respective tissues.

The extracts which appear to be without oxidases when tested in this manner have, in the majority of cases, a distinct acid reaction. This fact was noted by CLARK ${ }^{3}$ in summarizing the results of his own experiments. He concluded that extracts having an acidity such that ro cc. required $8 \mathrm{cc}$. $0 . \mathrm{I} \mathrm{N}, \mathrm{KOH}$ to neutralize to phenolphthalein were without oxidases.

The writer, proceeding in a similar manner with a considerable number of acid tissues, including several not previously tested, obtained results comparable with those reported by CLARK. He then made a series of special tests on Citrus fruits, probably the most acid of tissues, using a different method of examination, which seems to throw light on the general condition in acid tissues. Lemons, oranges, grape fruit, and kumquats were tried. In these fruits the juice is contained in long and enlarged sacs attached to the inside of the carpel walls. From this point of attachment they extend into the carpel, giving it the familiar honeycomb-like appearance. These sacs may be readily separated from the carpels and from one another without injuring their skin, which consists of 2-10 layers of cells. In this condition, when placed in a solution of gum guaiac, a-napthol, sodium selenite, or similar reagents, along with hydrogen peroxide, the surface of the hairs soon becomes covered with the colored compound resulting from the oxidation of the reagent. This indicates the presence of oxidases (or, according to the terminology of BACH and CHODAT, peroxidases, since hydrogen peroxide was required) in the cells of the sacs which contain the juice.

It is thus evident that Citrus fruits have normal oxidases in their acid tissues. It is also evident that these oxidases are protected in some manner from the action of the acid which at this concentration effectually inhibits the action of oxidases. It seems to the writer that this protection may be afforded by a semipermeable surface (the plasma membrane or cell walls similar to the cell walls of barley seed, which are impermeable to acid) through which the acid is unable to pass. When the tissue is ground, previous to pressing out the juice, the structure which separates the acid from the ferment is destroyed, so that the action of the latter is inhibited. That these membranes are not normally

${ }^{3}$ Clark, Torreya Ir : ror. I9Ir. 
permeable to acid is shown by the fact that seeds ${ }^{4}$ of lemons (which are separated from the acid by the walls of the sacs) frequently germinate while still in the carpels, though they will not germinate in lemon juice several times diluted.

It seems probable that this condition is a general one in acid tissues. The acid and ferment are separated in the tissue probably in a variety of ways, but the grinding destroys the separating surface, bringing acid and ferment in contact and inhibiting the action of the latter.

The general effects of acids and alkalies on oxidase ferments are now under investigation and will be reported on later--G. B. REED, Laboratory of Plant Physiology, Harvard University.

\section{THE TYPE SPECIES OF DANTHONIA}

In a recent paper, ${ }^{5}$ Professor A. S. HitchCock attempts to show that the type species of Danthonia DC. is Avena spicata L. instead of Festuca decumbens $\mathrm{L}$. If his arguments are to stand, stability in nomenclature will be an impossibility, for they are based purely on personal opinion. If a case in which there is doubt as to the type of a genus is to be decided on an interpretation of what the author may have thought most representative, it will never be disposed of, for this decision may vary with each succeeding systematist who faces the problem.

As emphasized at the Vienna Congress, one of the fundamental points in nomenclature ${ }^{6}$ "is to aim at fixity of names," and "in the absence of rule" (by which to bring this about) "established custom becomes law." However logical, therefore, Professor HrтcHсock's decision as to the type of Danthonia may be, it is essential for the sake of nomenclatural stability that the accepted custom of selecting the first species described (when the type is not indicated) be adhered to. Otherwise, as pointed out by Professor Нгтснсоск, some other botanist may say, "I favor selecting" $D$. provincialis DC. as the type.

Now Festuca decumbens is not only the first species described, but Professor HitchCock fails to show that DE CANDolle did not consider it completely congeneric with his $D$. provincialis. It is provided with an awn, even though rudimentary, and, to quote, "it is evident that the author considered the awn to be one of the important distinguishing characters of his new genus." DE CANDOLLE's suggestion that Avena

${ }^{4}$ The seeds of all the Citrus fruits examined showed an abundance of oxidases.

${ }_{5}^{5}$ The type species of Danthonia. Bot. Gaz. 57:328. I9I4.

${ }^{6}$ Vienna Rules, 35. 1905. 


\section{$2 \mathrm{BHL}$ Biodiversity Heritage Library}

Reed, G B . 1914. "The Oxidases of Acid Tissues." Botanical gazette 57(6), 528-530. https://doi.org/10.1086/331349.

View This Item Online: https://www.biodiversitylibrary.org/item/109459

DOI: https://doi.org/10.1086/331349

Permalink: https://www.biodiversitylibrary.org/partpdf/223584

\section{Holding Institution}

Missouri Botanical Garden, Peter H. Raven Library

\section{Sponsored by}

Missouri Botanical Garden

\section{Copyright \& Reuse}

Copyright Status: Public domain. The BHL considers that this work is no longer under copyright protection.

This document was created from content at the Biodiversity Heritage Library, the world's largest open access digital library for biodiversity literature and archives. Visit BHL at https://www.biodiversitylibrary.org. 